\title{
ASSESSMENT OF DNA DAMAGE USING CHROMOSOMAL ABERRATIONS ASSAY IN LYMPHOCYTES OF WATERPIPE SMOKERS
}

\author{
ENAS S. ALSATARI ${ }^{1}$, MOHAMMAD AZAB ${ }^{2}$, OMAR F. KHABOUR ${ }^{1}$, \\ KAREM H. ALZOUBI ${ }^{4}$, and MAY F. SADIQ ${ }^{5}$
}

${ }^{1}$ Jordan University of Science and Technology, Irbid, Jordan

Department of Applied Biological Sciences, Faculty of Science and Arts

${ }^{2}$ The Hashemite University, Zarqa, Jordan

Department of Community Medicine and Pathology, Faculty of Medicine

${ }^{3}$ Jordan University of Science and Technology, Irbid, Jordan

Department of Medical Laboratory Sciences, Faculty of Applied Medical Sciences

${ }^{4}$ Jordan University of Science and Technology, Irbid, Jordan

Department of Clinical Pharmacy, Faculty of Pharmacy

${ }^{5}$ Yarmouk University, Irbid, Jordan

Department of Biology, Faculty of Science

\begin{abstract}
Objectives: The aim of this study was to investigate the genotoxicity of waterpipe smoking in the lymphocytes of waterpipe smokers using chromosomal aberrations (CAs) assay. Materials and Methods: Fifty waterpipe smokers and 18 healthy nonsmokers volunteered to participate in the study. Additionally, 18 heavy cigarette smokers were recruited for comparison. Chromosomal aberrations (CAs) assay was used to evaluate DNA damage in the lymphocytes. Results: The results showed that similarly to cigarette smoking, waterpipe smoking significantly increased the frequencies of CAs $(\mathrm{p}<0.01)$. In addition, the frequencies of CAs increased with more waterpipe use. Conclusions: Waterpipe smoking causes DNA damage to lymphocytes and the damage increases with more waterpipe use.
\end{abstract}

Key words:

Waterpipe, Smoking, Cigarette, Chromosomal aberrations

Received: August 2, 2011. Accepted: March 19, 2012.

Address reprint request to M. Azab, Department of Community Medicine and Pathology, Faculty of Medicine, The Hashemite University, P.O. Box 150459, Zarqa 13115, Jordan (e-mail: azab_mohammed@hu.edu.jo). 


\section{INTRODUCTION}

Smoking is a major world health problem that kills more than 5 million people each year [1]. Tobacco smoke contains over 50 known carcinogens such as polycyclic aromatic hydrocarbon, N-nitrosamines and heavy metals [2]. Tobacco cigarette smoking is a causal agent of cancer, pulmonary and cardiovascular diseases, and nicotine/tobacco dependence [3-5].

Tobacco is commonly consumed in different ways including cigarette, cigar, and waterpipe (a.k.a. hookah, narghile, or shisha) smoking. The popularity of waterpipe smoking is growing in the eastern Mediterranean area and throughout the world especially among the youth [6-10]. This spread is, in part, due to the misperception that the waterpipe "filters" the smoke, rendering it less harmful than cigarette smoke $[11,12]$. Smoking using a waterpipe includes the use of a heavily flavored and hydrated, tobacco "moassel" that is burned by charcoal placed on top of the tobacco [13]. Similarly to cigarette, waterpipe smoke contains an abundance of several toxicants including polyaromatic hydrocarbons, aldehydes and heavy metals that are thought to render smokers more prone to cancer [14].

The DNA damage induced by cigarette smoking has been extensively studied [15]. Most reports indicate that cigarette smoking causes DNA damage as assessed by several tests including DNA adducts, micronuclei assay, sister chromatid exchanges (SCEs), 8-hydroxyguanosine, and chromosomal aberrations (CAs) [16-21]. However, the DNA damage associated with waterpipe smoking was examined in few studies. For example, a study by Khabour et al. [22] showed a significant increase in sister chromatid exchanges (SCEs) in the lymphocytes of waterpipe users. In addition, waterpipe smoking increases the levels of micronuclei in buccal mucosa cells of waterpipe users [23]. The aim of this study was to investigate the DNA damage associated with waterpipe smoking using CAs assay.

\section{MATERIALS AND METHODS}

\section{Subjects}

Fifty waterpipe smoker subjects with mean age of $26.5 \pm 4.2$ and 18 heavy smoker subjects with mean age of $25.2 \pm 5.4$ volunteered to participate in the study. Additional 18 nonsmoker subjects with mean age of $26.3 \pm 7.6$ were selected to match the smokers for age. The subjects were recruited from different places in Irbid city/Jordan such as coffee shops and student dorms. Waterpipe smokers were divided into three groups: 1) heavy smokers (Wh), i.e. those who used only waterpipe to smoke tobacco at least one time per day, 2) moderate smokers (Wm), who used waterpipe 4-5 days/week, and 3) light smokers group (Wl), who used waterpipe $<3$ days/week [22]. The heavy cigarette smokers group included those who used only cigarettes and smoked at least 30 or more cigarettes per day [22]. All subjects were healthy adult males and did not use alcohol or drugs. An institutional review board approval for the study was obtained and written informed consent was signed by all subjects according to the regulations of the Jordan University of Science and Technology.

\section{Chromosomal Aberrations Assay}

Chromosomal aberrations assay was performed as previously described [24]. Blood samples (5 $\mathrm{ml}$ each) were collected from the subjects from a peripheral vein using coded heparinized vacuum tubes. Lymphocyte cultures from fresh whole blood were established by adding $1 \mathrm{ml}$ to $9 \mathrm{ml}$ of PB max complete karyotyping media (Gibco-Invitrogen, UK). The cultures were incubated in the dark at $37^{\circ} \mathrm{C}$ for $72 \mathrm{~h}$ in a $\mathrm{CO}_{2}$ incubator. During the last $2 \mathrm{~h}$ of incubation, colcemid (final concentration of $0.1 \mu \mathrm{g} / \mathrm{ml}$ ) was added to arrest the cells in metaphase. The cultured cells were harvested by washing off the medium and then re-suspended in a pre-warmed hypotonic solution $(0.075 \mathrm{M} \mathrm{KCl})$ for $15-20 \mathrm{~min}$ at $37^{\circ} \mathrm{C}$. The swollen lymphocytes were collected by centrifugation, fixed in freshly prepared fixative [absolute ethanol : glacial acetic 
acid 3:1 (v:v)] at room temperature for $15 \mathrm{~min}$. The cells suspension was centrifuged, washed three times, and then re-suspended in $1 \mathrm{ml}$ of the fixative. The cellular suspension was then dropped on pre-chilled microscope slides to obtain metaphase spreads. The slides were allowed to air dry, aged for $24 \mathrm{~h}$ in a dark place and stained with 5\% Giemsa (Gainland chemical company, UK). Structural and numerical CAs were evaluated in 30 well-spread metaphases per donor. The evaluator was blind to the treatment. CAs were divided into gaps (including both chromatid gaps and chromosome gaps), breaks (including both chromatid breaks and chromosome breaks) and exchanges [25].

\section{Mitotic Index Analysis}

Themitoticindex(MI)wascalculated byanalyzing 1000 cells from each donor and scoring the cells that were in metaphase [26]. The changes in the MI values were used as indicators that reflect the cytotoxicity against blood lymphocytes.

\section{Statistical analysis}

The analysis of statistical significance was performed using Graphpad Prism statistical software (version 5.0). The data was expressed as a mean percent change from the control group \pm standard deviation. The Student t-test was used to compare CAs between the waterpipe and cigarette groups. To compare CAs between different waterpipe groups, ANOVA multiple comparison test followed by Newman-Keuls post hock test was used. A p $<0.05$ was considered significant.

\section{RESULTS}

Cytogenetic aberrations were observed in leukocytes using the black Giemsa staining technique, which only show up the asymmetrical chromosomal aberrations. Gaps, breaks and exchanges were included in the aberrations

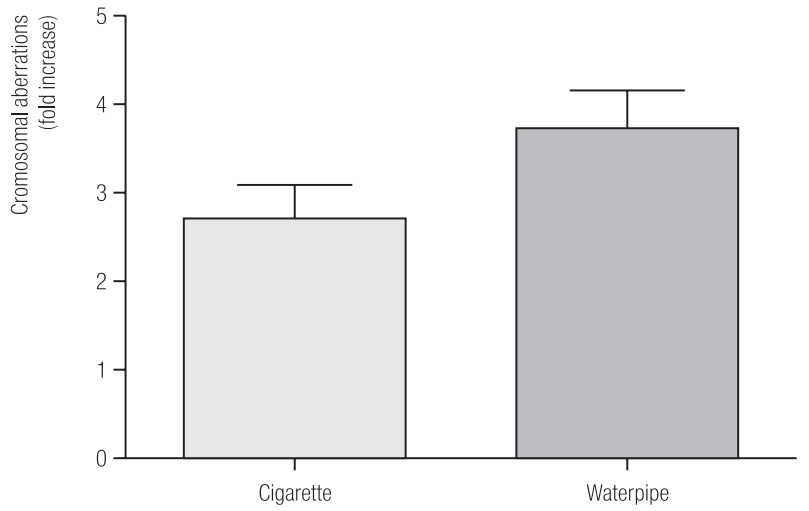

Chromosomal aberrations were examined in metaphase cells of cultured blood lymphocytes. The data is expressed as mean \pm SEM. Tobacco smoking using a cigarette or waterpipe significantly increased chromosomal aberrations ( $\mathrm{n}=18$ for the cigarette group and 50 for the waterpipe group; $\mathrm{p}<0.01$ ). The frequency of aberrations induced by waterpipe smoking was higher compared to cigarette smoking, but the difference was not statistically significant $(\mathrm{p}=0.178)$.

Fig. 1. Levels of chromosomal aberrations in lymphocytes from smokers and healthy controls

assessment. Cigarette smoking and waterpipe smoking significantly increase CAs by 2.7 and 3.7 fold, respectively $(\mathrm{p}<0.01$, Figure 1). The level of the increase in CAs was higher than that induced by cigarette smoking, but was not statistically significant $(p=0.178)$. Thus, the results indicate that tobacco smoking using cigarette or waterpipe induces significant aberrations in lymphocytes, and that the level of the induced aberrations is higher in waterpipe smokers than cigarette smokers.

To investigate whether CAs increase with more intense waterpipe use, waterpipe smokers were divided into heavy, moderate and light smokers depending on the use pattern. As shown in Figure 2, there were significant differences in the levels of CAs between the three groups (ANOVA, $\mathrm{F}=32.6, \mathrm{df}=49, \mathrm{p}<0.01)$. The level of CAs in Wh was higher than in the Wm group $(\mathrm{p}<0.01)$ and it was higher in the Wm than in the Wl group ( $p<0.05)$.

The mitotic index is used as an indicator that reflects the cytotoxicity against blood lymphocytes. The mitotic indices in waterpipe and cigarette smokers were higher than 


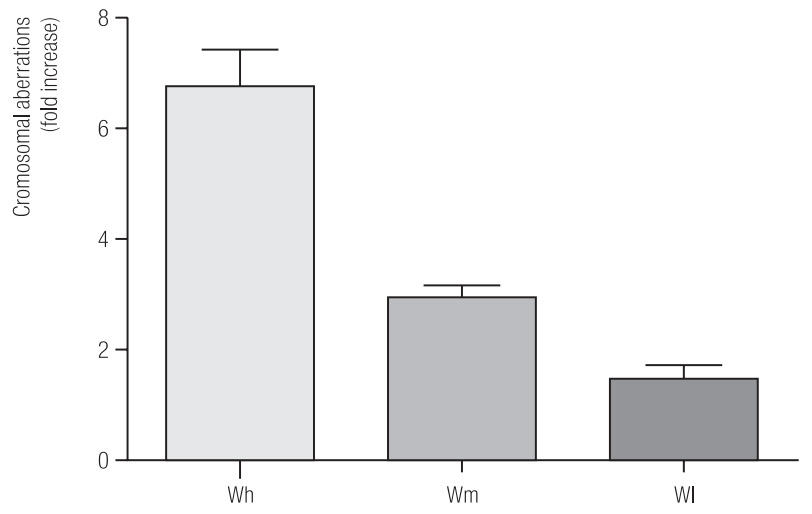

Waterpipe smokers were divided into heavy (Wh), moderate (Wm) and light $(\mathrm{Wl})$ according to their waterpipe use. The data is expressed as mean \pm SEM. The level of CAs in Wh was higher than in the Wm group $(\mathrm{p}<0.01)$ and it was higher in Wm than in the Wl group $(\mathrm{p}<0.05)$.

Fig. 2. Genotoxicity of waterpipe smoking increases with more waterpipe use

those of the controls (mean $\pm \mathrm{SE}=8.1 \pm 0.51,9.2 . \pm 1.2$, and 10.4 \pm 0.82 ; respectively) but this difference was not statistically significant $(\mathrm{p}>0.05)$.

\section{DISCUSSION}

In this study, we examined the DNA damage induced by waterpipe smoking on blood lymphocytes using CAs assays. This kind of assays is widely used especially in the genotoxicity assessment in human subjects [27]. In addition, multiple studies have shown a strong correlation between induction of CAs and the risk of cancer [28,29]. The results showed an approximately 4-fold increase in the level of CAs in waterpipe smokers compared to that present in healthy controls. This data is congruent with the study of Yadav and Thakur [30] that showed a significant increase in CAs in the lymphocytes among waterpipe users in India. In addition, waterpipe use has been shown to enhance the level of micronuclei in buccal mucosa cells of smokers [31]. Moreover, the level of sister chromatid exchanges in blood lymphocytes has been shown to be strongly correlated with waterpipe use [22]. Thus, waterpipe tobacco smoking is genotoxic to body cells and has the potential to be carcinogenic as indicated by the high level of CAs observed in this study.

The chromosomal aberrations test is widely used to investigate the potential DNA damage induced by various chemical and environmental agents including cigarette smoking. A study by Prabhavathi et al. [32] showed a significant increase in the frequency of CAs in the lymphocytes of cigarette smokers. Even occupational exposure to cigarette smoke has been demonstrated to increase the CAs frequency [33]. Cigarette smoking has also been shown to induce DNA damage using other genotoxic assays such as micronuclei [34], sister chromatid exchanges [20,35] and oxidative DNA damage [35] in the peripheral lymphocytes of smokers. The current results manifesting that cigarette smoking significantly increases the levels of CAs confirmed the previous findings and indicated the general genotoxic effects of tobacco smoking.

Compared to cigarette, waterpipe smoke contains more mutagenic and carcinogenic compounds [13,14]. For example, in comparison to a single cigarette, a single waterpipe smoking episode yielded 3-245 times the amount of polyaromatic hydrocarbons (PAHs) [13,14,36,37]. In addition, tar is two orders of magnitude greater than that produced from a single cigarette [38]. Moreover, the CO level is several folds higher in case of waterpipe smoking compared to cigarette smoking [39-41]. A meta-analysis study showed a significant association between lung cancer and waterpipe smoking [42]. Recently, a case control study of 251 lung cancer cases and 500 controls noted 5.8 odds ratio for the association of waterpipe smoking with lung cancer [43]. Thus, waterpipe smoke contains an abundance of several toxicants that are thought to render smokers more prone to cancer. The current results showed that the magnitude of the increase in CAs is correlated with the waterpipe use intensity. However, more studies are required with larger sample sizes and more assays to confirm the results. In addition, this study did not evaluate the genotoxicity in occasional 
waterpipe users and passive waterpipe smokers. The contribution of these variables to the level of genotoxicity and other groups like passive waterpipe smokers will be the subject of future research.

Induction of CAs by waterpipe tobacco smoking might be caused by different mechanisms. First, waterpipe smoke is very rich in PAHs such as Benzo(a)pyrine, Dibenz(a,h) anthracene, and Indeno(1,2,3-cd)pyrene that cause DNA lesions [44]. Second, burning of the "moassel" by the charcoal converts the added sugar into aldehyde compounds (e.g. Formaldehyde, Acetaldehyde and Acrolein) that causes DNA strand breaks $[45,46]$. Third, smoke produced by the charcoal contains heavy metals including arsenic, chromium and lead that have been shown to be mutagenic $[14,47]$. Finally, waterpipe smoke has been shown to increase the levels of free radicals that can result in the oxidative DNA damage, single strand breaks and chromosomal damage [48].

To sum up, waterpipe smoking is gentoxic and the extent of waterpipe-induced genotoxicity is higher than that of regular cigarette smoking. The results of the current study highlight the fact that regular waterpipe smoking is more harmful than regular cigarette smoking. The lack of regulations and policies regarding waterpipe smoking and waterpipe smoking products is alarming. A global effort is required to overcome the spread of waterpipe smoking. It should include 1) regulation of waterpipe products 2) initiation of policies against waterpipe smoking 3) development of special cessation programs for waterpipe smoking, and 4) providing support for the research that explores harmful effects of this type of smoking.

\section{ACKNOWLEDGMENTS}

The authors thank Mr. Almuthanna Alkaraki for his help with the recruitment of the subjects and blood collection. This work was supported from the Deanship of Research at Jordan University of Science and Technology (grant No.129/2008) and NIH (grant No. R03-TW008371).

\section{REFERENCES}

1. WHO. The Tobacco Epidemic. A Global Public Health Emergency. Tobacco or Health Programme on Substance Abuse. Geneva: WHO; 2009.

2. Rogers JM. Tobacco and pregnancy: overview of exposures and effects. Birth Defects Res C Embryo Today 2008;84(1): $1-15$.

3. Jha P. Avoidable global cancer deaths and total deaths from smoking. Nat Rev Cancer 2009;9(9):655-64.

4. Lee PN, Hamling J. The relation between smokeless tobacco and cancer in Northern Europe and North America. A commentary on differences between the conclusions reached by two recent reviews. BMC Cancer 2009;9:256. DOI: 10.1186/14712407-9-256.

5. Sasco AJ, Secretan MB, Straif K. Tobacco smoking and cancer: A brief review of recent epidemiological evidence. Lung Cancer 2004;45 Suppl 2:S3-9.

6. Azab M, Khabour OF, Alkaraki AK, Eissenberg T, Alzoubi KH, Primack BA. Water pipe tobacco smoking among university students in Jordan. Nicotine Tob Res 2010;12(6): 606-12.

7. Eissenberg T, Ward KD, Smith-Simone S, Maziak W. Waterpipe tobacco smoking on a U.S. College campus: prevalence and correlates. J Adolesc Health 2008;42(5):526-9.

8. Maziak W. The waterpipe: time for action. Addiction 2008;103(11):1763-7.

9. Primack BA, Sidani J, Agarwal AA, Shadel WG, Donny EC, Eissenberg TE. Prevalence of and associations with waterpipe tobacco smoking among U.S. university students. Ann Behav Med 2008;36(1):81-6.

10. Warren CW, Lea V, Lee J, Jones NR, Asma S, McKenna M. Change in tobacco use among 13-15 year olds between 1999 and 2008: findings from the Global Youth Tobacco Survey. Glob Health Promot 2009;16 Suppl 2:38-90.

11. Kandela P. Nargile smoking keeps Arabs in Wonderland. Lancet 2000;356(9236):1175.

12. Kiter G, Ucan ES, Ceylan E, Kilinc O. Water-pipe smoking and pulmonary functions. Respir Med 2000;94(9):891-4. 
13. Shihadeh A. Investigation of mainstream smoke aerosol of the argileh water pipe. Food Chem Toxicol 2003;41(1): $143-52$.

14. Shihadeh A, Saleh R. Polycyclic aromatic hydrocarbons, carbon monoxide, "tar", and nicotine in the mainstream smoke aerosol of the narghile water pipe. Food Chem Toxicol 2005;43(5):655-61.

15. DeMarini DM, Gudi R, Szkudlinska A, Rao M, Recio L, Kehl M, et al. Genotoxicity of 10 cigarette smoke condensates in four test systems: comparisons between assays and condensates. Mutat Res 2008;650(1):15-29.

16. Assis KR de, Ladeira MS, Bueno RC, Dos Santos BF, Dalben I, Salvadori DM. Genotoxicity of cigarette smoking in maternal and newborn lymphocytes. Mutat Res 2009; 679 (1-2):72-8.

17. DeMarini DM. Genotoxicity of tobacco smoke and tobacco smoke condensate: a review. Mutat Res 2004;567(2-3): $447-74$.

18. Karaoguz MY, Cosar B, Arikan Z, Basaran F, Menevse A, Menevse S. Increased frequency of sister chromatid exchanges in peripheral lymphocytes of alcoholics and cigarette smokers. Cell Biol Int 2005;29(2):165-8.

19. Lu Y, Morimoto K. Exposure level to cigarette tar or nicotine is associated with leukocyte DNA damage in male Japanese smokers. Mutagenesis 2008;23(6):451-5.

20. Rowland RE, Harding KM. Increased sister chromatid exchange in the peripheral blood lymphocytes of young women who smoke cigarettes. Hereditas 1999;131(2):143-6.

21. Tawn EJ, Whitehouse CA. Frequencies of chromosome aberrations in a control population determined by $G$ banding. Mutat Res 2001;490(2):171-7.

22. Khabour OF, Alsatari ES, Azab M, Alzoubi KH, Sadiq MF. Assessment of genotoxicity of waterpipe and cigarette smoking in lymphocytes using the sister-chromatid exchange assay: a comparative study. Environ Mol Mutagen 2011;52(3): 224-8.

23. El-Setouhy M, Loffredo ChA, Radwan G, Rahman RA, Mahfouz E, Israel E, et al. Genotoxic effects of waterpipe smoking on the buccal mucosa cells. Mutat Res 2008; 655(1-2):36-40.

24. Sadiq MF, Khabour OF, el-Shanti HE, Samawi HM. The effect of trifluoperazine on the genotoxicity of bleomycin in cultured human lymphocytes. Drug Chem Toxicol 2000;23(2): 361-9.

25. Saleh N, Khabour OF, Esmadi FT, Al-Kofahi E. In vivo cytogenetic studies on rat's bone-marrow cells of structurally related Schiff base complexes. Drug Chem Toxicol 2011;34(1): 92-9.

26. M'Bemba-Meka P, Lemieux N, Chakrabarti SK. Role of oxidative stress and intracellular calcium in nickel carbonate hydroxide-induced sister-chromatid exchange, and alterations in replication index and mitotic index in cultured human peripheral blood lymphocytes. Arch Toxicol 2007;81(2):89-99.

27. Kao-Shan CS, Fine RL, Whang-Peng J, Lee EC, Chabner BA. Increased fragile sites and sister chromatid exchanges in bone marrow and peripheral blood of young cigarette smokers. Cancer Res 1987;47(23):6278-82.

28. Norppa, H., Bonassi S, Hansteen I-L, Hagmar L, Strömberg U, Rössner P, et al. Chromosomal aberrations and SCES as biomarkers of cancer risk. Mutat Res 2006;600(1-2):37-45.

29. Ray GN, Shahid M, Husain S.A. Status of chromosome breaks and gaps in breast cancer. A follow-up study. Cancer Genet Cytogenet 2001;130(2):155-9.

30. Yadav JS, Thakur S. Genetic risk assessment in hookah smokers. Cytobios 2000;101(397):101-13.

31. Boulos DN, Loffredo CA, El Setouhy M, Abdel-Aziz F, Israel E, Mohamed MK. Nondaily, light daily, and moderateto-heavy cigarette smokers in a rural area of Egypt: a population-based survey. Nicotine Tob Res 2009;11(2):134-8.

32. Prabhavathi PA, Fatima SK, Rao MS, Reddy PP. Analysis of chromosomal aberration frequencies in the peripheral blood lymphocytes of smokers exposed to uranyl compounds. Mutat Res 2000;466(1):37-41.

33. Milic M, Kasuba V, Orescanin V, Zeljezic D, Kopjar N, Rozgaj R. Chromosome damage in workers in cigarette manufacturing industry. J Appl Toxicol 2008;28(3):399-404. 
34. Larramendy ML, Knuutila S. Increased frequency of micronuclei in $B$ and T8 lymphocytes from smokers. Mutat Res 1991;259(2):189-95.

35. Akbas E, Soylemez F, Derici E, Borekci G, Kanik A. Effects of X-rays and cigarette smoking on leukocyte, lymphocyte and mitotic index values and SCE rates: the relationship between mitotic index and lymphocyte count. Toxicol Ind Health 2003;19(2-6):81-91.

36. Monzer B, Sepetdjian E, Saliba N, Shihadeh A. Charcoal emissions as a source of $\mathrm{CO}$ and carcinogenic PAH in mainstream narghile waterpipe smoke. Food Chem Toxicol 2008;46(9):2991-5.

37. Sepetdjian E, Shihadeh A, Saliba NA. Measurement of 16 polycyclic aromatic hydrocarbons in narghile waterpipe tobacco smoke. Food Chem Toxicol 2008;46(5):1582-90.

38. Al Rashidi M, Shihadeh A, Saliba NA. Volatile aldehydes in the mainstream smoke of the narghile waterpipe. Food Chem Toxicol 2008;46(11):3546-9.

39. Bacha ZA, Salameh P, Waked M. Saliva cotinine and exhaled carbon monoxide levels in natural environment waterpipe smokers. Inhal Toxicol 2007;19(9):771-7.

40. Eissenberg T, Shihadeh A. Waterpipe tobacco and cigarette smoking: direct comparison of toxicant exposure. Am J Prev Med 2009;37(6):518-23.

41. Maziak W, Rastam S, Ibrahim I, Ward KD, Shihadeh A, Eissenberg T. CO exposure, puff topography, and subjective effects in waterpipe tobacco smokers. Nicotine Tob Res 2009;11(7):806-11.

42. Akl EA, Gaddam S, Gunukula SK, Honeine R, Jaoude PA, Irani J. The effects of waterpipe tobacco smoking on health outcomes: a systematic review. Int J Epidemiol 2010;39(3):834-57.

43. Koul PA, Hajni MR, Sheikh MA, Khan UH, Shah A, Khan Y, et al. Hookah smoking and lung cancer in the Kashmir valley of the Indian subcontinent. Asian Pac J Cancer Prev 2011;12(2):519-24.

44. Shinmura K, Iwaizumi M, Igarashi H, Nagura K, Yamada $\mathrm{H}$, Suzuki M, et al. Induction of centrosome amplification and chromosome instability in p53-deficient lung cancer cells exposed to benzo[a]pyrene diol epoxide (B[a]PDE). J Pathol 2008;216(3):365-74.

45. Daher N, Saleh R, Jaroudi E, Sheheitli H, Badr T, Sepetdjian E, et al. Comparison of carcinogen, carbon monoxide, and ultrafine particle emissions from narghile waterpipe and cigarette smoking: Sidestream smoke measurements and assessment of second-hand smoke emission factors. Atmos Environ 2010;44(1):8-14.

46. Lorenti Garcia C, Mechilli M, Proietti De Santis L, Schinoppi A, Kobos K, Palitti F. Relationship between DNA lesions, DNA repair and chromosomal damage induced by acetaldehyde. Mutat Res 2009;662(1-2):3-9.

47. Jose Zocche J, Dimer Leffa D, Paganini Damiani A, Carvalho F, Avila Mendonça R, Dos Santos CE, et al. Heavy metals and DNA damage in blood cells of insectivore bats in coal mining areas of Catarinense coal basin, Brazil. Environ Res 2010;110(7):684-91.

48. Salmon TB, Evert BA, Song B, Doetsch PW. Biological consequences of oxidative stress-induced DNA damage in Saccharomyces cerevisiae. Nucleic Acids Res 2004;32(12): 3712-23.

This work is available in Open Access model and licensed under a Creative Commons Attribution-NonCommercial 3.0 Poland License - http://creativecommons.org/ licenses/by-nc/3.0/pl/deed.en. 